\title{
NILAI RETENSI NITROGEN DAN ENERGI METABOLIS BROILER YANG DIBERI RANSUM TEPUNG LIMBAH SAWI PUTIH \\ (Brassica rapa L. subsp. pekinensis)
}

\author{
Fransisca The, J. S. Mandey*, Y. H. S. Kowel, M. N. Regar
}

Fakultas Peternakan, Universitas Sam Ratulangi Manado, 95115

\begin{abstract}
ABSTRAK
Penelitian ini bertujuan untuk mengetahui nilai retensi nitrogen $(\mathrm{RN})$ dan nilai energi metabolis terkoreksi nitrogen (AMEn) ransum broiler yang mengandung tepung limbah sawi. Penelitian dilakukan dengan menggunakan 18 ekor broiler MB 202 umur 6 minggu selama 6 hari yang terdiri dari 3 hari masa penyesuaian ransum dan 3 hari pengambilan data menggunakan metode total koleksi.. Rancangan yang digunakan adalah Rancangan Acak Lengkap (RAL) yang terdiri dari 3 perlakuan dan 6 ulangan. Perlakuan yang digunakan adalah: $\mathrm{R} 0=100 \%$ ransum dasar (RD) $+0 \%$ tepung limbah sawi (TLS), $\mathrm{R} 1=90 \% \mathrm{RD}+10 \%$ TLS dan $\mathrm{R} 2=80 \%$ $\mathrm{RD}+20 \%$ TLS. Variabel yang diteliti adalah nilai retensi nitrogen ( $\mathrm{RN})$ dan nilai energi metabolis terkoreksi nitrogen (AMEn). Hasil analisis keragaman menunjukkan bahwa perlakuan berbeda nyata $(\mathrm{P}<0,05)$ terhadap nilai $\mathrm{RN}$ dan berbeda sangat nyata $(\mathrm{P}<0,01)$ terhadap nilai AMEn. Hasil uji lanjut BNJ untuk nilai RN menunjukkan bahwa perlakuan R1 $(54,59 \%)$ dan perlakuan R2 $(41,71 \%)$ nayat menurun dibanding perlakuan R0 (71,02\%). Nilai AMEn pada perlakuan R1 $(2504,07 \quad \mathrm{Kkal} / \mathrm{kg})$ dan $\mathrm{R} 2$ $(2117,00 \mathrm{Kkal} / \mathrm{kg})$ nyata menurun dibanding dengan perlakuan R0 (3141,57 $\mathrm{Kkal} / \mathrm{kg}$ ). Dilihat dari nilai NR dan AMEn maka dapat disimpulkan bahwa tepung limbah sawi putih dapat digunakan dalam pakan broiler sampai $10 \%$.
\end{abstract}

\footnotetext{
*Korespondensi (corresponding Author) Email: jetsm fapet@yahoo.co.id
}

ta kunci : broiler, energi metabolis, limbah sawi, retensi nitrogen

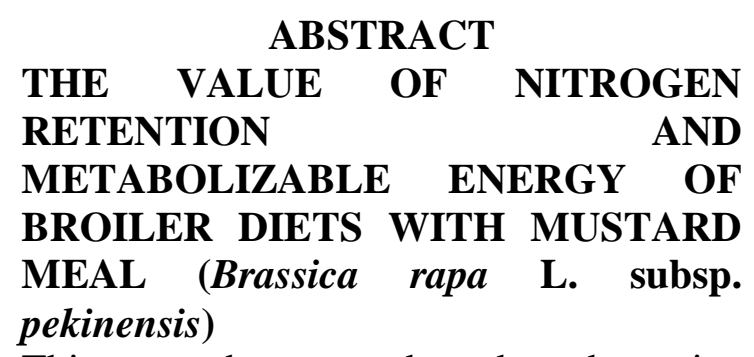

This research was conducted to determine the value of nitrogen retention (NR) and nitrogen corrected metabolizable energy value (AMEn) of broiler diets containing waste of mustard meal. Research used 18 MB 202 of broiler chickens 6 weeks of age that consists of 3 days of preliminary and 3 days collecting data. The experimental wasdesigned by a completely randomized design (CRD), which consists of 3 treatments and 6 replications. The treatmentswere: $\mathrm{R} 0=100 \%$ based diet (BD) $+0 \%$ mustard waste meal (MWM), $\mathrm{R} 1=90 \% \mathrm{BD}+10 \% \mathrm{MWM}$, and $\mathrm{R} 2=$ $80 \%$ BD $+20 \%$ MWM. Variables were nitrogen retention (NR) and metabolizable energy nitrogen corrected (AMEN) value. Results showed that the NR value was significantly $(\mathrm{P}<0.05)$ affected by treatments and the AMEn was highly significant $(\mathrm{P}<0.01)$ affected by treatments. HSD test showed thatthe NR value of $\mathrm{R} 1(54,59 \%)$ and $\mathrm{R} 2$ (41,71\%) was significantly decreased compared to control (41,71\%).The AMEn value oftreatment R1 (2504.07 Kcal/kg) and R2 $(2117.00 \mathrm{Kcal} / \mathrm{kg})$ was signicantly decreased compared to R0 (3141.57 $\mathrm{Kcal} / \mathrm{kg}$ ). Based on the NR and AMEn values, it can be concluded that mustard 
waste could be used up to $10 \%$ in dietof broilers

Keywords : broiler, metabolizable energy,mustard, nitrogen retention,

\section{PENDAHULUAN}

Limbah merupakan sampah yang mempunyai dampak pada manusia dan lingkungan antara lain kesehatan dan sosial ekonomi. Salah satu limbah yang banyak ditemui adalah limbah sayuran. Limbah sayuran berasal dari pertanian tanaman sayur-sayuran berupa produk samping/ikutan atau sisa-sisa sayuran yang sudah afkir dan tidak layakuntuk dipasarkan.

Secara fisik limbah sayuran mudah busuk karena berkadar air tinggi, namun secara kimia mengandung protein serta vitamin dan mineral yang relatif tinggi dan dibutuhkan oleh ternak. Limbah tersebut dapat menjadi sumber nutrisi bagi ternak, apabila diolah dengan teknologi yang baik dan benar.

Pemanfaatan limbah pertanian sebagai pakan ternak dapat menurunkan dampak negatifnya terhadap lingkungan dan memberikan keuntungan jika limbah dengan kualitas rendah dapat dimanfaatkan ternak untuk menghasilkan pangan berkualitas (Elferink, et al., 2008). Limbah sayuran berpotensi untuk dijadikan bahan pakan alternatif untuk broiler.Dilihat dari komposisi zat-zat makanan, limbah ini mengandung protein, vitamin dan mineral yang cukup tinggi, dan juga mengandung serat kasar yang cukup tinggi. Menurut Nawangwulansari (2012) kandungan protein kasar limbah sayuran 23\%dan kandungan energinya $3133 \mathrm{Kkal} / \mathrm{kg}$. Selanjutnya menurut Muktiani, dkk. (2013), limbah sayur pasar tradisional mengandung protein kasar $12,64 \%-23,50 \%$ dan serat kasar 20,76\% - 29,18\%. Hasil Analisis Laboratorium Ilmu dan Teknologi Pakan, Institut Pertanian Bogor (2016) kandungan protein limbah sawi 26,33\%, serat kasar 16,79\%, lemak 2,84\%, BETN 23,6\%, Ca 1,05\%, fosfor $0,37 \%$, abu $20,22 \%$, dan energi $3247 \mathrm{Kkal} / \mathrm{kg}$. Potensi limbah sawi cukup tinggi jika dilihat dari data statistik produksi sawi di Indonesia yaitu 117 ton/tahun dengan masa panen 85 ha (Badan Pusat Statistik dan Direktorat Jenderal Hortikultura, 2012).

Kecernaan suatu bahan menurut McDonald, et al. (2010) adalah bagian yang terserap dalam saluran pencernaan dan tidak dieksresikan dalam feses. Titus dan Fritz (1971) menyatakan bahwa tidak semua bahan pakan dapat dicerna dengan baik. Kegunaan penentuan kecernaan adalah untuk mendapatkan nilai bahan pakan secara kasar, sebab hanya bahan pakan yang dapat dicerna yang dapat diserap. McDonald, et al. (2010) 
menyatakan bahwa daya cerna suatu bahan pakan yang rendah akan mengakibatkan banyak energi hilang dalam bentuk ekskreta, sehingga nilai energi metabolis menjadi rendah.

Determinasi kecernaan pada unggas lebih rumit karena feses dan urin bercampur. Dalam perhitungan energi metabolis suatu bahan mungkin terjadi jumlah nitrogen feses dan urin lebih banyak dari jumlah nitrogen bahan yang dikonsumsi (retensi negatif) atau sebaliknya (retensi positif). Berdasarkan kemungkinan tersebut maka perhitungan energi metabolis perlu dikoreksi dengan keseimbangan nitrogen, yang diberi tanda AMEn (=apparent metabolizable energy nitrogen corrected) (Sibbald, 1982).

Penelitian tentang kecernaan limbah sayuran sudah pernah dilakukan pada ayam kampung superdengan cara pengukusan, perebusan dan penjemuran, ditambahkan sebanyak $15 \%$ dalam ransum, hasil menunjukkan nilai kecernaan bahan kering yang cukup tinggi pada perlakuan pengukusan (Abun, 2007). Penelitian tentang kecernaan pakan mengandung tepung limbah sawi belum pernah dilakukan, sehingga berdasarkan pemikiran tersebut maka telah dilakukan penelitian dengan menggunakan tepung limbah sawi dalam ransum broiler terhadap nilai retensi nitrogen dan energi metabolis ransum.

\section{MATERI DAN METODE PENELITIAN}

Penelitian ini telah dilaksanakan di Kandang Fakultas Peternakan Universitas Sam Ratulangi Manado, sejak tanggal 30 April 2016 sampai 5 Mei 2016 atau 3 hari masa penyesuaian ransum dan 3 hari pengambilan data menggunakan metode total koleksi. Sebelumpengambilan data, ayam dipuasakan selama 15 jam. Penelitian ini menggunakan 18 ekor broiler MB 202 umur 6 minggu dengan rataan berat badan \pm 931 gram .

Kandang yang digunakan adalah kandang

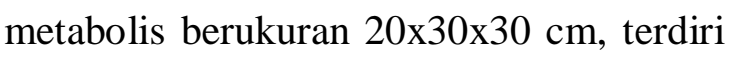
dari 18 unit kandang yang dilengkapi dengan tempat makan dan minum. Perlengkapan lain yang digunakan adalah timbangan digital Ohaus (untuk menimbang ayam, ransum dan ekskreta), wadah penampung ekskreta, tabung penyemprot, aluminium foil, pengaduk dan oven untuk mengeringkan ekskreta. Bahan kimia yang digunakan selama percobaan ini adalah asam borat $5 \%$.

Bahan pakan penyusun ransum terdiri dari jagung kuning (58\%), dedak halus (5\%), tepung ikan (15\%), tepung kedele (11\%), bungkil kelapa (9\%), minyak kelapa (1\%) dan mineral mix 
(1\%). Komposisi ransum, kandungan zatzat makanan dan energi metabolis ransum percobaan dapat dilihat pada Tabel 1.

Penelitian ini menggunakan Rancangan Acak Lengkap (RAL) menurut petunjuk Steel and Torrie (1995), yang terdiri dari 3 perlakuan dan 6 ulangan. Data yang diperoleh dianalisis, dan untuk hasil yang berbeda dilanjutkan dengan uji lanjut Beda Nyata Jujur (BNJ).

Variabel yang diukur yaitu retensi nitrogen dan energi metabolis menurut petunjuk Zarei (2006) dengan menggunakan rumus :

1. Retensi Nitrogen (RN)

$$
\mathrm{RN}(\%)=\frac{(\mathrm{F} i \times \mathrm{NN} f)-(\mathrm{E} \times \mathrm{N} e)}{(\mathrm{F} i \times \mathrm{N} f)} \times 100 \%
$$

Keterangan :

$\mathrm{RN} \quad$ : Retensi Nitrogen (\%)

$\mathrm{N} f \quad$ : Nitrogen Pakan (\%)
$\mathrm{Ne} \quad$ : Nitrogen Ekskreta(\%)

$\mathrm{Fi} \quad$ : Pakan yang dikonsumsi (g)

E : Jumlah Ekskreta (g)

2. Energi Metabolis (AMEn)

$$
\begin{aligned}
& =\frac{(\mathrm{F} i \times \mathrm{GE} f)-(\mathrm{E} \times \mathrm{GE} e)-(\mathrm{NR} \times \mathrm{K})}{\mathrm{F} i}
\end{aligned}
$$

Keterangan :

AMEn : Energi metabolis semu yang dikoreksi dengan retensi nitrogen $(\mathrm{Kkal} / \mathrm{kg})$

$\mathrm{Fi} \quad$ : Banyaknya pakan yang dikonsumsi (g)

E : Jumlah Ekskreta (g)

GE $f \quad$ : Energi Bruto pakan (Kkal/kg)

GEe: Energi Bruto ekskreta (Kkal/kg)

$\mathrm{NR} \quad$ : Retensi Nitrogen $(\mathrm{g}) \mathrm{NR}=(\mathrm{F} i$ $\mathrm{x} \mathrm{N} f)-(\mathrm{E} \times \mathrm{N} e)$

$\mathrm{K} \quad$ : Konstanta koreksi untuk nilai energi nitrogen yang diretensi $(8.73 \mathrm{Kkal} / \mathrm{kg}$ untuk setiap gram nitrogen)

Tabel 1. Komposisi Ransum, Kandungan Zat-zat Makanan dan Energi Bruto Ransum Percobaan*

\begin{tabular}{lccc}
\hline \multicolumn{1}{c}{ Perlakuan } & R0 & R1 & R2 \\
\hline \multicolumn{1}{c}{ Ransum Basal } & 100 & 90 & 80 \\
& 0 & 10 & 20 \\
\hline Zat Makanan (\% bahan kering) & & & \\
\hline Protein (\%) & 14,34 & 15,89 & 16,21 \\
Lemak (\%) & 7,23 & 6,86 & 7,24 \\
Serat Kasar (\%) & 4,49 & 5,57 & 6,08 \\
Ca (\%) & 0,93 & 1,18 & 1,53 \\
P (\%) & 0,08 & 0,26 & 0,23 \\
Abu (\%) & 6,08 & 6,89 & 8,55 \\
EB (Kkal/kg) & 3972 & 4222 & 4351
\end{tabular}

Keterangan : *) Hasil Analisis Laboratorium Ilmu dan Teknologi Pakan, Institut Pertanian Bogor (2016) 


\section{HASIL DAN PEMBAHASAN}

Rataan nilai retensi nitrogen $(\mathrm{RN})$ dan nilai energi metabolis terkoreksi nitrogen (AMEn) ransum menggunakan tepung limbah sawi pada broiler disajikan pada Tabel 2.

\section{Pengaruh Perlakuan Terhadap Nilai Retensi Nitrogen Ransum Broiler}

Rataan nilai $\mathrm{RN}$ ransum mengandung tepung limbah sawi dalam penelitian ini berkisar antara 41,71\%sampai 71,02\%. Hasil analisis keragaman menunjukkan bahwa penggunaan tepung limbah sawi dalam ransum memberikan pengaruh berbeda nyata $(\mathrm{P}<0.05)$ terhadap nilai $\mathrm{NR}$, danhasil uji BNJ menunjukkan

Retensi nitrogen merupakan salah satu metode untuk menilai kualitas protein ransum dengan mengukur konsumsi nitrogen dan pengeluaran nitrogen dalam feses dan urin sehingga dapat diketahui jumlah nitrogen yang tertinggl dalam tubuh (Farrell,1974). Apabila nitrogen yang dikonsumsi lebih besar daripada nitrogen yang diekskresikan maka nilai retensi nitrogen positif, sedangkan retensi nitrogen negatif apabila yang dikonsumsi lebih kecil daripada nitrogen yang diekskresikan. Hasil retensi nitrogen pada penelitian ini adalah bernilai positif.

Retensi nitrogen padapenelitian ini lebih tinggi dibandingkan dengan yang dilaporkan McLeod,et al. (1988), bahwa retensi nitrogen pada ayam pedaging umur 7 minggu dapat mencapai 1,50 - 1,73g ekor ${ }^{-}$ ${ }^{1}$ hari $^{-1}$ pada galur langsing (leon) dan 1,87 - 2,10 g ekor ${ }^{-1}$ hari $^{-1}$ pada galur gemuk (fat).Mateos, et al., 1982) menyatakan bahwa lebih banyak nitrogen yang diretensi tersebut antara lain disebabkan oleh proses pencernaan dan absorpsi zatzat makanan yang lebih baik sehingga mempercepat rate of passagRetensi nitrogen $(\mathrm{g})$ padapenelitian ini lebih tinggi dibandingkan dengan yang dilaporkan McLeod,et al. (1988), bahwa retensi nitrogen pada ayam pedaging umur 7 minggu dapat mencapai 1,50 - 1,73g ekor ${ }^{-}$ ${ }^{1}$ hari $^{-1}$ pada galur langsing (leon) dan 1,87 - 2,10 g ekor ${ }^{-1}$ hari $^{-1}$ pada galur gemuk (fat).Mateos, et al., 1982) menyatakan bahwa lebih banyak nitrogen yang diretensi tersebut antara lain disebabkan oleh proses pencernaan dan absorpsi zatzat makanan yang lebih baik sehingga mempercepat rate of passage. 
Tabel 2. Rataan Nilai Retensi Nitrogen dan Energi Metabolis Terkoreksi Nitrogen Ransum Menggunakan Tepung Limbah Sawi

\begin{tabular}{lccc}
\hline \multicolumn{1}{c}{ Parameter } & \multicolumn{3}{c}{ Perlakuan } \\
\cline { 2 - 4 } & $\mathrm{R} 0$ & $\mathrm{R} 1$ & $\mathrm{R} 2$ \\
\hline Konsumsi Protein (g) & 44,80 & 43,19 & 42,80 \\
RN (g) & $3,51^{\mathrm{a}}$ & $2,80^{\mathrm{a}}$ & $2,32^{\mathrm{b}}$ \\
RN (\%) & $71,02^{\mathrm{a}}$ & $54,59^{\mathrm{b}}$ & $41,71^{\mathrm{c}}$ \\
AMEn (Kkal/kg) & $3141,57^{\mathrm{a}}$ & $2504,07^{\mathrm{b}}$ & $2117,00^{\mathrm{c}}$ \\
& $(79,09 \%)$ & $(59,31 \%)$ & $(48.65 \%)$ \\
\hline
\end{tabular}

Keterangan : - Superskrip yang berbeda pada baris yang sama menunjukkan adanya perbedaan yang nyata $(\mathrm{P}<0.05)$

- $\mathrm{RN}=$ retensi nitrogen; AMEn = energy metabolis terkoreksi nitrogen

Nilai RN tertinggi pada hasil penelitian ini terdapat pada perlakuan R0 dengan kandungan protein ransum $14,34 \%$, dan semakin menurun pada perlakuan R1 dan perlakuan R2 yang diberi limbah sawi putih dengan kandungan protein ransum $15,89 \%$ dan $16,21 \%$ berturut-turut. Hal ini sesuai pendapat Ewing (1963) yang menyatakan bahwa retensi nitrogen menurun dengan meningkatnya protein ransum. Menurut McDonald, et al. (2010) bahwa retensi nitrogen tergantung pada kandungan protein dalam ransum. Kandungan nitrogen yang diretensi sejalan dengan kandungan protein ransum. Wahju (2004) menyatakan bahwa pakan dengan protein rendah bergerak lebih cepat meninggalkan saluran pencernaan dibandingkan dengan pakan yang kandungan proteinnya tinggi, pergerakannya lebih lambat meninggalkan saluran pencernaan untuk mendapatkan waktu lebih banyak untuk proses denaturasi dan penglarutan protein yang dikonsumsi. Hasil penelitian ini tidak sejalan dengan yang dilaporkan Dady, dkk. (2016) dan Mandey, et al. (2016) menyatakan bahwa dengan kandungan protein yang sama (20\%) pada setiap perlakuan, pemberian $6 \%$ daun murbei (Morus alba) dalam ransum broiler nyata menurunkan nilai RN, AMEn dan kecernaan lemak dibanding ransum kontrol.

Retensi nitrogen dipengaruhi oleh beberapa faktor, yaitu: konsumsi ransum, konsumsi protein dan kualitas protein. Konsumsi protein dan retensi nitrogen berbanding lurus. Konsumsi protein dalam penelitian ini cenderung menurun dan persentase retensi nitrogen nyata semakin menurun dari R0 sampai R2. Namun jumlah retensi nitrogen (g) pada R0 dan R1 tidak berbeda dan nyata menurun pada R2. Nitrogen yang diretensi ini menggambarkan efisiensi penggunaan 
protein pada broiler. Retensi nitrogen bernilai positif artinya bahwa tubuh broiler tersebut mendapatkan pertambahan bobot badan karena tenunan ototnya bertambah.

\section{Pengaruh Perlakuan Terhadap Nilai}

\section{Energi Metabolisme Ransum Broiler}

Rataan nilai energi metabolis pada broiler berkisar antara 2117,00 $\mathrm{Kkal} / \mathrm{kg}$ sampai 3141,57 Kkal/kg. Nilai energi metabolis tertinggi diperoleh pada perlakuan R0, selanjutnya diikuti oleh perlakuan R1 dan R2. Hasil analisis keragaman menunjukkan bahwa penggunaan tepung limbah sawi dalam ransum broier memberikan pengaruh berbeda nyata $(\mathrm{P}<0,01)$ terhadap nilai AMEn dan hasil uji BNJ menunjukkan bahwa perlakuan R0, R1 dan R2 berbeda nyata . Perlakuan menggunakan tepung limbah sawi pada level pemberian $10 \%$ dan 20\% menyebabkan nilai AMEn nyata menurun dibandingkan dengan ransum kontrol atau tanpa menggunakan tepung limbah sawi.

Nilai AMEn dalam penelitian ini masih lebih rendah dibanding dengan penelitian Newkirk, et al. (1997) yang membandingkan penggunaan Brassica juncea (sawi daging) dengan Brassica rapa (sawi putih) dan mendapatkan nilai AMEn sawi putih adalah $1557 \mathrm{Kkal} / \mathrm{kg}$ dan nilai daya cerna protein ileal 76,72\%. Menurunnya nilai energi metabolis pada perlakuan menggunakan tepung limbah sawi diduga disebabkan oleh kandungan serat kasar yang cukup tinggi dalam ransum (4.95\%-6.27\%). Dengan demikian, penyerapan zat makanan tidak optimal terutama penyerapan energi dalam ransum yang dikonsumsi menjadi kurang, yang ditandai dengan adanya kecenderungan menurunnya nilai energi metabolis pada perlakuan R1 dan R2. Bila dilihat dari kandungan energi bruto ransum pada R0 sebesar $3972 \mathrm{Kkal} / \mathrm{kg}, \quad \mathrm{R} 1$ sebesar $4222 \mathrm{Kkal} / \mathrm{kg}$ dan R2 sebesar $4351 \mathrm{Kkal} / \mathrm{kg}$, dan energi yang dikeluarkan dalam feses maka energi yang termetabolis berturutturut adalah sebagai berikut R0 : 79,09\%, R1 : 59,31\% dan R2 : 48.65\%. Hapsari (2006) mendapatkan bahwa nilai energi metabolis ransum ayam broiler yang mengandung limbah restoran sangat nyata lebih rendah dibanding nilai energi metabolis ransum yang mengandung dedak padi bila dilihat dari nilai AMEn.

Menurut Ani, et al (2012) bahwa penggunaan pakan berbasis hijauan memberi efek peningkatan serat kasar ransum yang berdampak pada pemanfaatan energi oleh broiler. Jimenez, et al. (2013) melaporkan bahwa peningkatan total serat kasar dalam ransum nyata akan mempengaruhi retensi nutrien (bahan kering, bahan organik dan nitrogen). 


\section{KESIMPULAN}

Dilihat dari nilai retensi nitrogen dan persentase energi yang termetabolis maka dapat disimpulkan bahwa limbah sawi putih dapat digunakan sampai $10 \%$ dalam ransum broiler.

\section{DAFTAR PUSTAKA}

Abun., D. Rusmana, D. Saefulhadjar. 2007. Efek pengolahan limbah sayuran secara mekanis terhadap nilai kecernaan pada ayam kampung super JJ-101. J. Ilmu Ternak, Vol. 7 (2): 8186.

Ani, A. O., O. D Omeje and L. C. Ugwuwowo. 2012. Effect of raw Bambara nut (Voandzeia subterranea) and apparent nutrition retention in broiler chicken. African J. of Biotech., 11(56): 11991-11997.

Badan Pusat Statistik dan Direktorat Jenderal Hortikultura. 2012. Pedoman Teknis Pelaksanaan Pengembangan Hortikultura Tahun 2012. Kementerian Pertanian,Direktorat Jenderal Hortikultura.

Dady, Z., J.S. Mandey, M.R. Imbar, M.N. Regar. 2016. Nilai retensi nitrogen dan energy metabolis ransum menngunakan daun murbei (Morus alba) segar pada broiler. J. Zootek ('Zootek J.), Vol. 36 (1): 42-50.

Elferink, E.V., S. Nonhebel, H.C. Moll. 2008. Feeding livestock food residue and the consequences for the environmental impact of meat. J. Clean. Prod., 16: 1227-1233.

Ewing, W. R. 1963. Poultry Nutrition. $5^{\text {th }}$ Ed.The Ray Ewing Company Publiser. Pasadena. California.
Farrell, D.J. 1974. Effects of dietary energyconcentration on utilization of energy by broiler chickens and body composition determined by carcass analysis and predicted using tritium. Brit. Poult. Sci. 15: 25.

Hapsari, R.P. 2006. Energi Metabolis dan Effisiensi Penggunaan Ransum Ayam Broiler yang Mengandung Limbah Restoran Sebagai Pengganti Dedak Padi.Skripsi.Program Studi Nutrisi dan Makanan Ternak, Fakultas Peternakan, Institut Pertanian Bogor.

Jimenez, E.M., M. Frikha, A. de Coca Sinova, J. Garcia, and G.G. Mateos. 2013. Oat hulls and sugar beet pulp in diet of broilers; Effect on growth performance and nutrient digestibility. Anim. Feed Sci. Tech., 182: 33-43.

Mandey, J.S., C.A. Rahasia, Z. Dady. 2016. Digestibility value of broiler diet containing fresh mulberry (Morus alba) leaves. Proceeding.The $17^{\text {th }}$ Asian-Australasian Association of Animal Production Societies Animal Science Congress. Fukuoka, Japan, 22-24 August, 2016.

Mateos, G.G., J.L. Sell, and J.A. Eastwood. 1982.Rate of food passage (transit time) as influence by level supplemental fat. Poult. Sci.61: 94 100.

McDonald, P., R.A. Edwards, J.F.D. Greenhalgh, C.A. Morgan, L.A. Sinclair,, and R.G. Wilkinson. 2010. Animal Nutrition. $7^{\text {th }}$ Ed. Prentice Hall, Pearson, Harlow, England, London, New York, Boston, San Fransisco, Toronto, Sydney, Tokyo, Singapore, Hong Kong, Seoul, Taipei, New Delhi, Cape Town, Madrid, 
Mexico City, Amsterdam, Munich, Paris, Milan.

McLeod, M.G., C.C. Whitehead, H.D. Griffin, and T.R. Jewitt. 1988. Energi and nitrogen retention and loss broiler chickens genetically selected for leanness and fatness. Brit. Poult.Sci.67: 285-292.

Muktiani, A.J., Achmadi, B.I.M. Tampubolon, dan R. Setyorini. 2013. Pemberian silase limbah sayuran yang disuplementasi dengan mineral dan alginate sebagai pakan domba. J. Pengembangan Peternakan Tropis, 2: 144-150.

Nawangwulansari, 2012.Penggunaan Limbah Organik Pasar Sebagai Pengganti Dedak Hingga 30\% Pada Ransum Ternak Itik Petelur.Skripsi.Fakultas Peternakan Universitas Diponegoro, Semarang.

Newkirk, R.W., H.L. Classen, R.T. Tyler. 1997. Nutritional evaluation of low glucosinolate mustard meals (Brassica juncea) in broiler diet. Poult. Sci. 76: 1271-1277.

Sibbald, I.R. 1982. Measurement of bioavailable energy in poultry feedingstuffs. Ca. J. of Anim. Sci., 62: 983-1048.

Steel, R. G. D., dan J. H. Torrie 1995.Prinsip dan Prosedur Statistika : Suatu Pendekatan Biometrik. Terjemahan B. Sumantri. Gramedia Pustaka Utama, Jakarta.

Titus, H.W., and J.C. Fritz. 1971. The Scientific Feeding of Chickens. $5^{\text {th }} \mathrm{Ed}$. The Interstate Printers \& Publishers, Inc. Danville, Illinois.

Wahju, J. 2004. Ilmu Nutris Unggas. Edisi ke-4. Gadjah Mada University Press, Yogyakarta.
Zarei, A. 2006.Apparent and true metabolizable energy in Artemia meal.Int. J. of Poult. Sci.,5(7): 627628. 